\title{
A Cooperative OSDA Blueprint for Highly Siliceous Faujasite Zeolite Catalysts with Enhanced Acidity Accessibility
}

\author{
Quanli Ke, Ibrahim Khalil, Brent Smeyers, Zheng Li, Rodrigo de Oliveira-Silva, Bert Sels, \\ Dimitrios Sakellariou, and Michiel Dusselier**
}

\begin{abstract}
A cooperative OSDA strategy is demonstrated, leading to novel high-silica FAU zeolites with a large potential for disruptive acid catalysis. In bottom-up synthesis, the symbiosis of choline ion $\left(\mathrm{Ch}^{+}\right)$and 15-crown-5 (CE) was evidenced, in a form of full occupation of the sodalite (sod) cages with the trans $\mathrm{Ch}^{+}$conformer, induced by the $\mathrm{CE}$ presence. $C E$ itself occupied the supercages along with additional gauche $\mathrm{Ch}^{+}$, but in synthesis without $\mathrm{CE}$, no trans was found. The cooperation, and thus the fraction of trans $\mathrm{Ch}^{+}$, was closely related to the Si/Al ratio, a key measure for FAU stability and acidity. As such, a bottom-up handle for lowering the Al-content of FAU and tuning its acid site distribution is shown. A mechanistic study demonstrated that forming sod cages with trans $\mathrm{Ch}^{+}$is key to the nucleation of high-silica FAU zeolites. The materials showed superior performances to commercial FAU zeolites and those synthesized without cooperation, in the catalytic degradation of polyethylene.
\end{abstract}

\section{Introduction}

Zeolites are crystallized microporous materials composed of well-defined channels and cages, which widely serve the fields of adsorption and catalysis. ${ }^{[1,2]}$ Having 12-memberedring openings, FAU materials, with pore apertures of $7.35 \AA$ and supercage dimensions of $11.24 \AA$, are excellent performers in various processes such as fluid catalytic cracking (FCC), biofuel upgrading, biomass conversion and plastic waste degradation. ${ }^{[3-8]}$ However, the high framework Al contents of these zeolites from their as-made form has to be addressed

[*] Dr. Q. Ke, Dr. I. Khalil, B. Smeyers, Prof. Dr. B. Sels,

Prof. Dr. M. Dusselier

Center for Sustainable Catalysis and Engineering, KU Leuven

Celestijnenlaan 200F, 3001 Heverlee (Belgium)

E-mail: michiel.dusselier@kuleuven.be

Dr. Q. Ke

Institute of Catalytic Reaction Engineering, College of Chemical

Engineering, Zhejiang University of Technology

Chaowang Road 18, 310014 Hangzhou (China)

Dr. Z. Li

Department of Chemistry, KU Leuven

Celestijnenlaan 200F, 3001 Heverlee (Belgium)

Dr. R. de Oliveira-Silva, Prof. Dr. D. Sakellariou

Centre For Membrane Separations, Adsorption, Catalysis and Spectroscopy for Sustainable Solutions (cMACS), KU Leuven Celestijnenlaan 200F, p.o. box 2454, 3001 Heverlee (Belgium) since it severely interferes with their acid strength, (hydro)thermal stability and thus their catalytic activity. ${ }^{[9-11]}$ Even though various post-synthesis methods have been adopted to remove a part of the framework $\mathrm{Al}$ species, including hydrothermal dealumination and fluoride etching, the iterative treatments by acid or alkaline solutions result in loss of crystallinity, creation of defects and possibly side reactions in catalysis associated with the extra-framework species. ${ }^{[12-17]}$ In this setting, the direct synthesis of FAU zeolite with higher $\mathrm{Si}$ / $\mathrm{Al}$ ratios is very attractive.

Table S1 gathers the state-of-the-art synthesis protocols for high-silica FAU. As seen, the $\mathrm{Si} / \mathrm{Al}$ molar ratios in the final zeolite products can barely surpass 3 under organic-free conditions (Entries 1 and 2, Table S1), even though great efforts have been made by carefully adjusting the synthesis parameters or by introducing hydroxyl radicals. ${ }^{[18,19]}$ This supposed limit is due to the decrease in the crystallization rate, or the increase in the apparent activation energy, when increasing the $\mathrm{Si} / \mathrm{Al}$ ratio in the crystallization product. ${ }^{[20]}$ In order to address this dilemma, a series of organic structuredirecting agents (OSDAs) with different volumes and charge densities, (Choline $\left(\mathrm{Ch}^{+}\right)$, tetraethylammonium $\left(\mathrm{TEA}^{+}\right)$, inositol, 15-crown-5 (CE), etc.) have been adopted in search for optimal host-guest interaction (Entries 3-10, Table S1). However, it remains a great challenge to obtain crystalized FAU zeolites with $\mathrm{Si} / \mathrm{Al}$ ratio higher than 5. One possible reason might be the high alkali metal amounts in reactant gels, as indicated by the $\mathrm{Na}^{+} / \mathrm{Si}$ ratios in Table S1. Recently, Liu et al. have reported a two-step synthesis of highly siliceous FAU zeolite with $\mathrm{Si} / \mathrm{Al}$ around 7 using low alkali amounts, the bulky quaternary tetrabutylammonium OSDA $\left(\mathrm{TBA}^{+}\right)$, and relatively high temperatures (Entry 11, Table S1). ${ }^{[21]}$ However, the exact location of the quaternary alkylammonium ions, the nature of the surface acidity, and the synthesis mechanism are not fully elucidated. The use of a pre-crystallized nuclei solution containing a second OSDA $\left(\mathrm{TEA}^{+}\right)$was required, making the synthesis rather difficult and delicate. ${ }^{[21]}$ Thus, a robust and simple recipe for high-silica FAU zeolite is strongly desired, in particular one that leads to clear acidity characterizations, making use of OSDA positioning. Here, the crystallization barrier is the most significant problem to tackle, which necessitates greater driving forces deriving from the host-guest interaction, zeolite seeding, and high temperature.

Normally, molecular configuration, hydrophobic-hydrophilic properties and charge density are considered as the determining factors for the host-guest interaction between an OSDA and the zeolite framework. ${ }^{[22]}$ However, the conforma- 
tional (isomer) diversity of OSDAs has also proven to carry an important influence on the topology structure and chemical composition, especially within the constrained environment of a zeolite. ${ }^{[23,24]} \mathrm{A}$ remarkable example of this is $\mathrm{Ch}^{+}$, which could direct the formation of various zeolite structures although its structure is rather simple. ${ }^{[25-28]}$ Hong et al. further verified, with Raman spectroscopy, the coexistence of two $\mathrm{Ch}^{+}$types within different zeolites, namely gauche and trans conformer (Figure S1). ${ }^{[29]}$ In terms of FAU topology, specifically, a small fraction of trans $\mathrm{Ch}^{+}$conformer $(8 \%)$ has been detected in the sod cage in addition to the predominant occupancy of gauche conformer in the supercage (Entry 5, Table S1). ${ }^{[29]}$ In contrast, as a conventional OSDA for medium high-silica FAU synthesis $(\mathrm{Si} / \mathrm{Al}=4.5)$, $\mathrm{CE}$ was found to locate in supercages only, in the form of a cationic complex with $\mathrm{Na}^{+}$(entry 10, Table S1). ${ }^{[30-32]}$ Given this, it is reasonable to surmise that higher contents of trans $\mathrm{Ch}^{+}$conformer might be confined, or pushed to occlude, within the sod cage when a bulky OSDA is present in the supercage as a second OSDA. In this way, less alkali metal amount, as well as less $\mathrm{Al}$ content should be required because of the physical or electrostatic repulsive forces between the charged OSDAs and the alkaline metal cations. Furthermore, the Al location and acid sites distribution within FAU zeolite may change correspondingly due to the interaction between framework and specifically located organic templates.

Herein, the one-step synthesis of high-silica FAU zeolite has been realized by adopting a cooperative OSDA strategy where trans $\mathrm{Ch}^{+}$conformer was captured in the sod cage, while gauche $\mathrm{Ch}^{+}$conformer and $\mathrm{CE}$ complex $\left(\mathrm{Na}^{+}-15-\right.$ crown-5) constructed the supercage (Scheme 1). Reactant sources, choline concentration, seeds amount, and reaction temperature were delicately screened to achieve the optimum cooperation between $\mathrm{Ch}^{+}$and $\mathrm{CE}$. Owing to the unique sensitivity of Raman spectroscopy to both the $\mathrm{Ch}^{+}$conformation and the FAU zeolite framework, spectra were collected in a time profile to reveal the formation and evolution of building units during crystallization. Finally, the protonic high-silica FAU zeolites were applied to the catalytic degradation of low-density polyethylene (LDPE), where they showed superior catalytic performances and good stability in comparison to other homemade and commercial FAU and USY zeolites. Advanced characterizations indicate that the

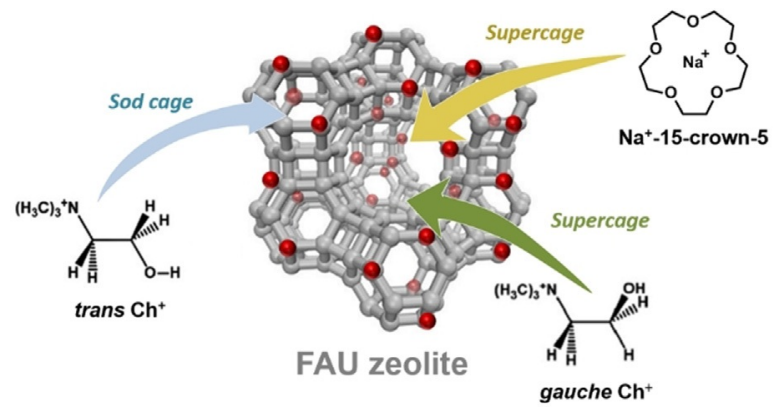

Scheme 1. The cooperative OSDA blueprint using $\mathrm{Ch}^{+}$and $\mathrm{Na}^{+}-15-$ crown-5 (CE complex) for high-silica FAU zeolite synthesis. The Al atoms in red are randomly inserted, but the $\mathrm{Si} / \mathrm{Al}=6$ ratio of the structure is accurate, with 3-4 Al per sod cage. smaller crystal sizes and the higher fraction of accessible Brønsted acid sites, likely linked to the OSDA positioning, within the high-silica FAU zeolite played a significant role in this acid-catalyzed process.

\section{Results and Discussion}

An optimization for different parameters (e.g. Si and $\mathrm{Al}$ sources, choline hydroxide $(\mathrm{ChOH})$ concentration, and $\mathrm{CE}$ concentration) was performed in order to select the optimal conditions in which the trans $\mathrm{Ch}^{+}$can be captured in sod cages (Table S2,S3). Compared with TEOS and $\mathrm{Al}(\mathrm{OPr})_{3}$, Ludox AS-40 and $\mathrm{NaAlO}_{2}$ are more advantageous sources with respect to product crystallinity and synthesis times (Table S3). The most promising results in terms of pure FAU structure were obtained when using Ludox AS-40 and $\mathrm{NaAlO}_{2}$ with $\mathrm{ChOH} / \mathrm{Na}^{+}=3$ and $\mathrm{CE} / \mathrm{Na}^{+}=1$ (Table S3, Figure S2). The starting $\mathrm{Si} / \mathrm{Al}$ ratio, the added zeolite seeds, and the synthesis temperature can also profoundly impact the formation of high-silica FAU. In general, highly crystallized FAU zeolites could be readily synthesized with a starting $\mathrm{Si} / \mathrm{Al}$ ratio up to 10 , zeolite seeds amount up to 7 wt. \%, and synthesis temperatures up to $130^{\circ} \mathrm{C}$ according to our multi-parameter screening (Figures S3-S5, Table S4). The addition of zeolite seeds seems necessary for the construction of high-silica FAU, and both the seeds amount and their $\mathrm{Si} / \mathrm{Al}$ ratios (or their solubility in alkaline environments, Figure S6) have significant influences on the crystallinity of FAU products (Figure S4, Figure S7). FAU zeolites with $\mathrm{Si} / \mathrm{Al}=30$ (CBV760 from Zeolyst) were identified as good seeds (from trials with 4 different seed zeolites, Figure S7). Meanwhile, it should also be noted that, the $\mathrm{Si} / \mathrm{Al}$ ratios of the products were found to increase slightly with the amount of seeds (from 6.0 with $1 \%$ seeds to 6.4 with $7 \%$ seeds) and synthesis temperature (from 5.8 at $120^{\circ} \mathrm{C}$ to 6.0 at $130^{\circ} \mathrm{C}$, using $1 \%$ seeds), which could be linked to the stronger driving force from seeding and heat to overcome the crystallization barrier.

To further investigate the properties of high-silica FAU zeolites, pure faujasite zeolites were selected from optimal and representative synthesis conditions, namely: FAU-S1, FAU-S2, FAU-S3, and FAU-S4 (Table 1 and Entries 13, 17, 26, and 39 in Table S2), and these were compared with FAU$\mathrm{CH}$ and FAU-CE benchmarks, synthesized using only $\mathrm{Ch}^{+}$or CE, respectively (Table 1). ${ }^{[30,33]}$ FAU-S1 and FAU-S2 were selected because of their pure FAU phase obtained with high seeds loading $(10 \%)$ at different temperatures $\left(110^{\circ} \mathrm{C}\right.$ and $120^{\circ} \mathrm{C}$, respectively); highly siliceous FAU-S3 and FAU-S4 were chosen because of their minute seed usage $(1 \%)$, which would not significantly change the overall gel composition, but translates to a higher seeding efficiency and a potentially lower manufacturing cost as indicated by the solid product yields (Table S2, entries 26-29, entries 39-42). In consideration of the gel composition differences between the highsilica FAU and the two benchmark samples (e.g. $\mathrm{Na}^{+}, \mathrm{H}_{2} \mathrm{O}$, seeds amount), another six benchmark recipes were carried out with similar synthesis compositions of FAU-S4 but using $\mathrm{CE}$ or $\mathrm{Ch}^{+}$as the only OSDA (so digressing from reported "CE or $\mathrm{Ch}^{+}$only" recipes in literature) (Table S2, entries 46- 
Table 1: The synthesis conditions and resultant properties of high-silica FAU zeolites.

\begin{tabular}{|c|c|c|c|c|c|c|c|c|c|}
\hline Sample & $T\left[{ }^{\circ} \mathrm{C}\right]$ & $\mathrm{Si} / \mathrm{Al}$ & $\mathrm{Na}^{+} / \mathrm{Si}$ & $\mathrm{Si} / \mathrm{Al}^{[\mathrm{e}]}$ & Yield [\%] & $\begin{array}{l}\text { FAU Product } \\
\text { Crystal shape and Size }[\mu \mathrm{m}]^{[\mathrm{f}]}\end{array}$ & $\begin{array}{l}15-\mathrm{crown}-5 / \mathrm{Ch}^{+} \\
{[\mathrm{mol} / \mathrm{mol}]^{[\mathrm{g}]}}\end{array}$ & $\%$ trans $\mathrm{Ch}^{+[h]}$ & Entry number ${ }^{[j]}$ \\
\hline $\mathrm{FAU}-\mathrm{CH}^{[\mathrm{a}]}$ & 110 & 5 & 0.40 & 3.5 & 50.4 & Polyhedrons, 1.0-1.2 & 0 & 0 & Entry 1 \\
\hline FAU-CE $E^{[b]}$ & 110 & 5 & 0.48 & 4.5 & 66.3 & Polyhedrons, 1.5-1.7 & $\infty$ & - & Entry 2 \\
\hline $\mathrm{FAU}-\mathrm{S} 1^{[\mathrm{c}]}$ & 110 & 7 & 0.14 & 4.8 & 39.0 & Polyhedrons, $0.1-0.2$ & 0.53 & 17.0 & Entry 13 \\
\hline FAU-S2 ${ }^{[c]}$ & 120 & 7 & 0.14 & 5.0 & 41.8 & Polyhedrons, $0.1-0.3$ & 0.50 & 33.5 & Entry 17 \\
\hline FAU-S3 ${ }^{[d]}$ & 120 & 10 & 0.14 & 5.8 & 48.6 & Polyhedrons, $0.2-0.5$ & 0.61 & 39.2 & Entry 26 \\
\hline FAU-S4 ${ }^{[\mathrm{d}]}$ & 130 & 10 & 0.14 & $6.0^{[1]}$ & 41.0 & Polyhedrons, $0.4-0.7$ & 0.60 & 51.9 & Entry 39 \\
\hline
\end{tabular}

[a] Initial gel: $5 \mathrm{SiO}_{2: 1} \mathrm{NaAlO}_{2: 1} \mathrm{NaOH}: 1 \mathrm{ChOH}: 100 \mathrm{H}_{2} \mathrm{O}$. [b] Initial gel: $10 \mathrm{SiO}_{2}: 1 \mathrm{Al}_{2} \mathrm{O}_{3}: 2.4 \mathrm{Na}_{2} \mathrm{O}: 1$ 15-crown-5:140 $\mathrm{H}_{2} \mathrm{O}$. [c] Initial gel: $14 \mathrm{SiO}_{2}: x \mathrm{Al}_{2} \mathrm{O}_{3}: 1 \mathrm{Na}_{2} \mathrm{O}: y \mathrm{ChOH}: 2$ 15-crown-5:144 $\mathrm{H}_{2} \mathrm{O}, 10$ wt \% of CBV760 zeolites, based on $\mathrm{SiO}_{2}$ amount, were added into the initial gels as seeds. More detailed recipes in Table S2. All the reactant gels were stirred under room temperature for $48 \mathrm{~h}$ before reaction under desired temperature in oven. [d] The same recipe with footnote $c$ but with only $1 \mathrm{wt} \%$ of CBV760 zeolite seeds. [e] Measured by ICP-AES. [f] Determined by SEM.

[g] Determined from $\mathrm{C} / \mathrm{N}$ elemental analyses. [h] The percentage of the trans conformer of $\mathrm{Ch}^{+}$ions in each zeolite was determined by dividing the Raman band area centered at $782 \mathrm{~cm}^{-1}$ by the sum of band areas centered at $782 \mathrm{~cm}^{-1}$ and $715 \mathrm{~cm}^{-1}$. [i] Average of three ICP measurements. Values of 6 or higher were measured in 8 samples. [j] Refers to the Entry number in Table S2 and this referral is used as well below.

51). The majority product in all these benchmark recipes was never FAU (Figures S8,S9).

Noticeably, highly crystallized FAU zeolites could still be synthesized under much lower $\mathrm{Na}^{+} / \mathrm{Si}$ ratios $(0.14)$ than FAU$\mathrm{CH}(\mathrm{CE})$ methods (Figure S10A, Table 1). In the meantime, higher organic weight loss was witnessed in the FAU zeolites synthesized here, which partially explains their high $\mathrm{Si} / \mathrm{Al}$ ratios (Figure S10B). Moreover, while different decomposition regions were observed on FAU-CE $\left(170-425^{\circ} \mathrm{C}\right)$ and
FAU-CH $\left(250-650^{\circ} \mathrm{C}\right)$ in TGA, the organic weight loss occurred in the whole temperature range over high-silica FAU zeolites (e.g. FAU-S4, Figure 1A), indicating the presence of the two templates therein. Their mutual presence was further validated by ${ }^{13} \mathrm{C}$ MAS NMR of the as-prepared FAU-S4, which relates well to the ${ }^{13} \mathrm{C}$ liquid NMR spectra of intact $\mathrm{Ch}^{+}$and $\mathrm{CE}$ (Figure S11). Interestingly, multiple peaks were witnessed in FAU-CH zeolite which could indicate the magnetically non-equivalent environments of $\mathrm{Ch}^{+}$in its
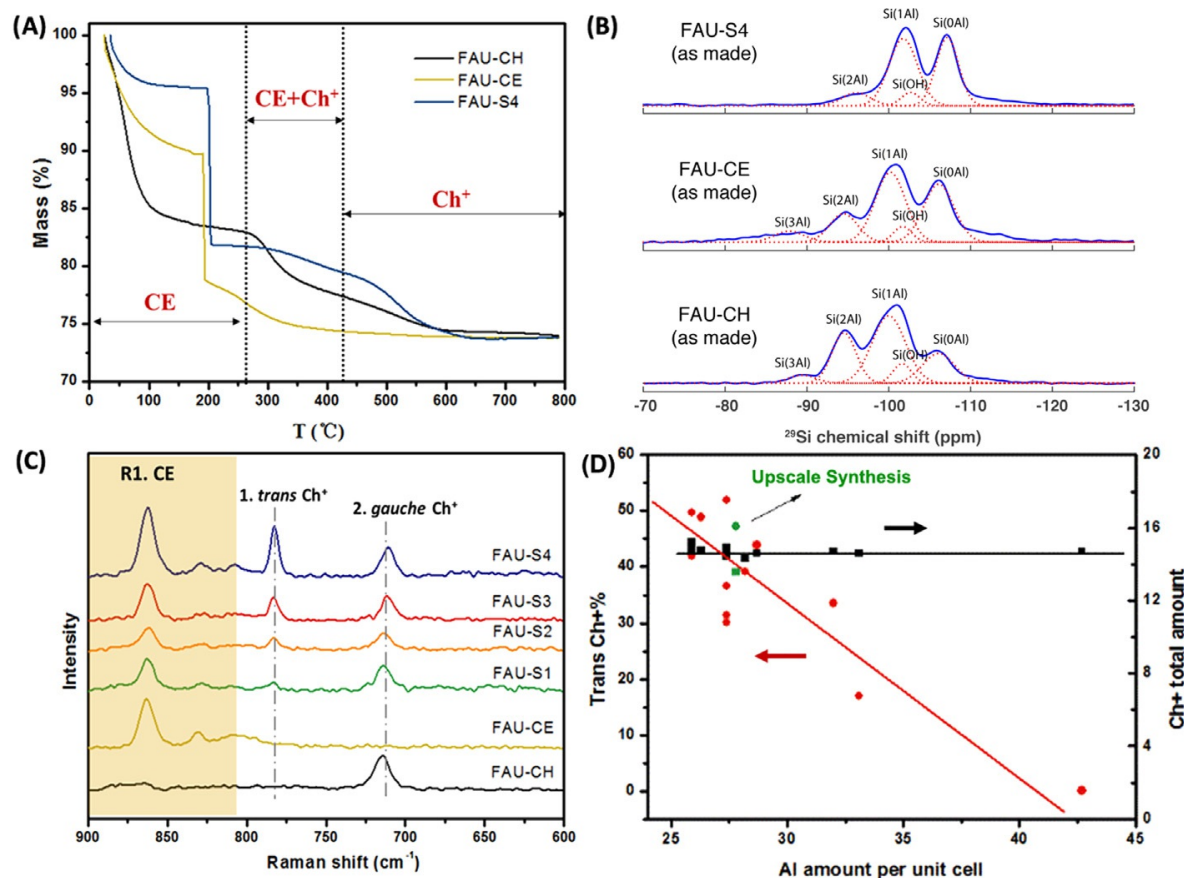

Figure 1. A) Thermogravimetric weight loss of the as-made FAU-S4 (Entry 39) with comparison to FAU-CH (Entry 1) and FAU-CE (Entry 2), see Figure S10B for more information about FAU-S1 (Entry 13), FAU-S2 (Entry 17) and FAU-S3 (Entry 26). B) ${ }^{29}$ Si MAS NMR spectra of the as-made FAU-S4 (Entry 39) in comparison with FAU-CH (Entry 1) and FAU-CE (Entry 2). The red dotted lines show the deconvolution of the peaks using Gaussian line shapes. See the spectra for calcined samples in Figure S14 and deconvolution results in Table S5. C) Raman spectra patterns of the as-made FAU zeolites. R1.CE: coupled $\mathrm{CO}$ stretching and $\mathrm{CH}_{2}$ rocking of $\mathrm{CE}$ complex; Band $1\left(782 \mathrm{~cm}^{-1}\right): v_{\mathrm{s}}(\mathrm{C}-\mathrm{N})$ of trans $\mathrm{Ch}^{+}$conformer in sod cage of FAU zeolite; Band $2\left(715 \mathrm{~cm}^{-1}\right): v_{\mathrm{s}}(\mathrm{C}-\mathrm{N})$ of gauche $\mathrm{Ch}^{+}$conformer in supercage of FAU zeolite. (D) The changes of total $\mathrm{Ch}^{+}$amount and trans $\mathrm{Ch}^{+}$fraction per unit cell versus the increment of $\mathrm{Al}$ atoms in each unit cell of $\mathrm{FAU}$ zeolites. $25.9 \mathrm{Al}$ per unit cell translates to $\mathrm{Si} / \mathrm{Al}=6.4$, while $42.7 \mathrm{Al}$ per unit cell translates to $\mathrm{Si} / \mathrm{Al}=3.5$. See more details in Table S6. Each dot (left axis) is accompanied by a square (right axis). The green points refer to the upscale sample of the FAU-S4 recipe (Entry 57 ). 
supercage. On the contrary, a single magnetic environment was observed in FAU-S4, which may reflect certain mobility of trans and gauche $\mathrm{Ch}^{+}$in its sod cage and supercage, respectively (see later). ${ }^{29} \mathrm{Si}$ MAS NMR spectra in Figure 1 B primarily include five resolved signals, namely $\mathrm{Si}(0 \mathrm{Al})=[\mathrm{Si}-$ $\left.(\mathrm{OSi})_{4}\right], \quad \mathrm{Si}(\mathrm{OH})=\left[\mathrm{Si}(\mathrm{OSi})_{3}(\mathrm{OH})_{1}\right], \quad \mathrm{Si}(1 \mathrm{Al})=\left[\mathrm{Si}(\mathrm{OSi})_{3^{-}}\right.$ $\left.(\mathrm{OAl})_{1}\right], \mathrm{Si}(2 \mathrm{Al})=\left[\mathrm{Si}(\mathrm{OSi})_{2}(\mathrm{OAl})_{2}\right]$, and $\mathrm{Si}(3 \mathrm{Al})=\left[\mathrm{Si}(\mathrm{OSi})_{1}\right.$ $\left.(\mathrm{OAl})_{3}\right] \cdot{ }^{[34,35]}$ The presence of $\mathrm{Si}(\mathrm{OH})$ signal could also be confirmed by the more significant enhancement of $\mathrm{Si}(1 \mathrm{Al})$ signal enhancement with respect to $\mathrm{Si}(0 \mathrm{Al})$ signal in cross polarization (dynamics) experiments (see more details in Figures S12,S13). According to the deconvolution results, the spectra of FAU-CH and FAU-CE show an aluminous framework with even $\mathrm{Si}(3 \mathrm{Al})$ signals, in line with ICP results and previously reported values in literature (Table 1). ${ }^{[30,33]}$ By contrast, a clearly more siliceous ${ }^{29} \mathrm{Si}$ MAS NMR spectrum, with notably no $\mathrm{Si}(3 \mathrm{Al})$, is found for FAU-S4. ICP-AES confirms this, with repeatable high $\mathrm{Si} / \mathrm{Al}$ values of 6 (=for FAU-S4, higher values up to 6.4 were even found, for related samples). Such a siliceous FAU cannot be realized by using a single OSDA. This clearly confirms the benefits of our dual template strategy. To further verify the content of amorphous silica within FAU zeolites, the framework Si/Al ratios have been calculated basing on the spectra deconvolution (Figure $1 \mathrm{~B}$, Figure S14, Table S5). The calculated Si/Al values are highly coincident with the values derived from ICP-AES analyses, which suggests that there exists little amount of amorphous silica within the FAU zeolites (Table S5). Additionally, the ${ }^{27} \mathrm{Al}$ MAS NMR spectra of all three zeolites in both as-made and calcined forms show only one signal centered at ca. $60 \mathrm{ppm}$, which suggests little presence of extraframework alumina (Figure S15).

Raman spectra were recorded to shed light on the occluded state of the OSDAs in the zeolite. Especially, information about the conformation of $\mathrm{Ch}^{+}$is interesting as it greatly affects its interaction with the zeolite framework. Results in Figure 1C mainly show three characteristic bands: the first, "R1.CE" at around $860 \mathrm{~cm}^{-1}$ is the coupled $v(\mathrm{C}-\mathrm{O})$ stretching and $\delta\left(\mathrm{CH}_{2}\right)$ rocking of the CE complex, while the two other bands are assigned to the symmetric $\mathrm{C}-\mathrm{N}$ stretching $v_{\mathrm{s}}(\mathrm{C}-\mathrm{N})$ of different conformation of $\mathrm{Ch}^{+}$in FAU zeolites: (1) trans $\mathrm{Ch}^{+}$conformer in the sod cage (FAU) at $782 \mathrm{~cm}^{-1}$ and (2) the gauche $\mathrm{Ch}^{+}$conformer in the supercage (FAU) at $715 \mathrm{~cm}^{-1} \cdot{ }^{[29,31]}$ Interestingly, the $\mathrm{Ch}^{+}$ions are merely present as gauche conformers in the absence of $\mathrm{CE}$, as is the case with FAU-CH zeolite (Figure 1C), whereas both trans $\mathrm{Ch}^{+}$and gauche $\mathrm{Ch}^{+}$conformers are present after using the cooperative OSDA protocols (FAU-S1 to FAU-S4). Moreover, according to the relative Raman band intensity of gauche and trans $\mathrm{Ch}^{+}$conformer, the $\mathrm{Al}$ content built into the zeolites are found to correlate inversely with the fraction of trans $\mathrm{Ch}^{+}$ (thus in sod cages) occluded (Figure 1D, Table 1). The Al per unit cell decreases, and thus $\mathrm{Si} / \mathrm{Al}$ ratio increases, as more trans $\mathrm{Ch}^{+}$in $\operatorname{sod}$ cages is found. Figure $1 \mathrm{D}$ remarkably also shows that the total $\mathrm{Ch}^{+}$amount occluded per unit cell does not change. In order to validate this correlation, an upscale synthesis of FAU-S4 (8 times, yielding $4.9 \mathrm{~g}$ organic-free zeolites) was conducted and the data points (green) were located in similar region with those of FAU-S4 in Figure 1D.
Altogether, this strongly indicates the synergy between the dual templates, enabling $\mathrm{Ch}^{+}$into the sod cages. This synergy was further verified during the screening of synthesis condition: in presence of inadequate conditions, sod units with trans $\mathrm{Ch}^{+}$conformer occlusion preferentially aggregated into SOD zeolite $\left(765 \mathrm{~cm}^{-1}\right.$ in Raman spectra), rather than cooperated with CE to form FAU zeolite $\left(782 \mathrm{~cm}^{-1}\right.$ in Raman spectra) (Figures S16,S17).

With the Si/Al ratios, organic contents, and conformer fractions of the zeolites confirmed, the unit cell compositions of the as-synthesized zeolites were calculated (Table S6). For example, FAU-S4 represents: $\left[\mathrm{Ch} g_{7.1} \mathrm{Ch} t_{7.6} \mathrm{CE}_{8.8} \mathrm{Na}_{12.7^{-}}\right.$ $\left.\left(\mathrm{H}_{2} \mathrm{O}\right)_{40.7}\right]\left[\mathrm{Al}_{27.4} \mathrm{Si}_{164.6} \mathrm{O}_{384}\right]$, with $\mathbf{C h g}$ the gauche and $\mathbf{C h} \boldsymbol{t}$ the trans conformer. A unit cell of FAU contains 8 sod cages and 8 supercages. The molar ratios between $\mathrm{CE}$ and $\mathrm{Ch}^{+}$were determined by elemental analysis (Table 1, Table S2). In the case of FAU-S4, for example, each unit cell contains 7.1 gauche $\mathrm{Ch}^{+}, 7.6$ trans $\mathrm{Ch}^{+}$, and $8.8 \mathrm{CE}$, which corresponds to 1.0 trans $\mathrm{Ch}^{+}$per sod cage and 0.9 gauche $\mathrm{Ch}^{+}$along with 1.1 $\mathrm{CE}$ per supercage, respectively. These findings interestingly confirm our aim for the selective capture of trans $\mathrm{Ch}^{+}$within sod cages, and the full accommodation of the supercage with $1 \mathrm{Ch}^{+}$and $1 \mathrm{CE}$. In other words, compared to pure $\mathrm{Ch}^{+}$ synthesis, the presence of a second OSDA, herein CE, leads to a cooperative behavior favoring replacement of gauche $\mathrm{Ch}^{+}$ by $\mathrm{CE}$ in the supercage while promoting the formation or pushing the occlusion of trans $\mathrm{Ch}^{+}$in sod cages. As a result, less $\mathrm{Na}^{+}$is found in the sod (and other) cages of the FAU zeolites because of the more severe steric hindrance and electrostatic repulsive forces inside the sod cage, which leads to less $\mathrm{Al}$ and thus higher $\mathrm{Si} / \mathrm{Al}$ ratios (Table S6). The great role that $\mathrm{CE}$ played in promoting the transformation of $\mathrm{Ch}^{+}$ was also reflected by the varied trans $\mathrm{Ch}^{+}$factions in the final products when different amounts of $\mathrm{CE}$ and $\mathrm{ChOH}$ were encountered (Figure S18,S19). Specifically, even though a small fraction of trans $\mathrm{Ch}^{+}$was found in the amorphous $\mathrm{Ch}^{+}$-only benchmark (754 $\mathrm{cm}^{-1}$ in Raman spectra), they seem not capable of guiding the formation of $\operatorname{sod}$ cages $\left(782 \mathrm{~cm}^{-1}\right.$ in Raman spectra absent) in absence of CE (Figure S20) and thus could not lead to the FAU forming in these conditions. When compared to the highly siliceous FAU zeolite from Liu et al., ${ }^{[21]}$ with unit cell composition of $\left(\mathrm{H}_{2} \mathrm{O}\right)_{27} \mathrm{Na}_{11.3} \mathrm{TEA}_{2.8} \mathrm{TBA}_{9.9}\left(\mathrm{Si}_{168} \mathrm{Al}_{24} \mathrm{O}_{384}\right)$, the $\mathrm{Na}^{+}$amount therein is close to that of FAU-S4; however, the $\mathrm{Na}^{+}$has occupied the sod cages in their case, whereas most of the $\mathrm{Na}^{+}$ in FAU-S4 $\left(\mathrm{Na}^{+} / \mathrm{CE}=1.4\right)$ is likely settled in the supercage since CE molecules always appear as cationic complex with $\mathrm{Na}^{+}$. In this way, $\mathrm{Al}$ location and acid sites distributions are likely different and these affect the catalytic properties.

Since FAU-S4 exhibits attractive properties including short synthesis time and high silica content, a time profile using XRD and Raman spectra has been constructed to reveal the crystallization mechanism. As shown in Figure 2 A, FAU phase started appearing after $72 \mathrm{~h}$ under $130^{\circ} \mathrm{C}$, and fully crystallized FAU was obtained after $120 \mathrm{~h}$. The values in the parentheses stand for the crystallinity of solid products. As for Raman spectra, no signals except for $v_{\mathrm{s}}(\mathrm{C}-\mathrm{N})\left(\mathrm{ca} .715 \mathrm{~cm}^{-1}\right)$ and $v_{\text {as }}(\mathrm{C}-\mathrm{N})\left(\mathrm{ca} .960 \mathrm{~cm}^{-1}\right)$ of gauche $\mathrm{Ch}^{+}$were noticed till $48 \mathrm{~h}$, which corresponds to the amorphous patterns in XRD 

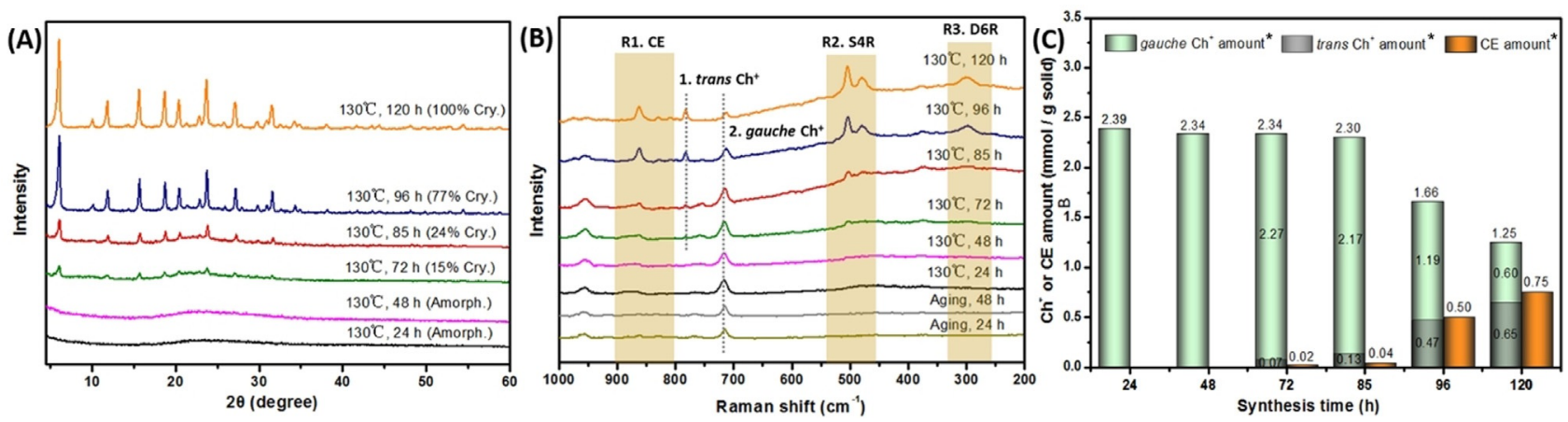

Figure 2. The changes of A) XRD patterns, B) Raman spectra patterns, and C) $\mathrm{Ch}^{+}$amount and $\mathrm{CE}$ amount per gram of solid versus the increasing of synthesis time. (Synthesis recipe based on FAU-S4 as Entry 39). In (A), the details of crystallinity calculation were shown in Section 2 of SI. In (B), R1.CE: coupled CO stretching and $\mathrm{CH}_{2}$ rocking of CE complex; R2.S4R: breathing mode vibrations of S4R in FAU zeolite; R3.D6R: bending mode vibrations of D6R in FAU zeolite; Band 1: $v_{\mathrm{s}}(\mathrm{C}-\mathrm{N})$ of trans $\mathrm{Ch}^{+}$conformer in sod cage of FAU zeolite; Band 2: $v_{\mathrm{s}}(\mathrm{C}-\mathrm{N})$ of gauche $\mathrm{Ch}^{+}$conformer in supercage of FAU zeolite or amorphous solid products. In (C), $\mathrm{Ch}^{+}$and $\mathrm{CE}$ amounts were determined by the TGA analyses and $\mathrm{C} / \mathrm{N}$ elemental analyses of solid products. Trans $\mathrm{Ch}^{+}$amounts were calculated by the relative Raman band intensity of gauche (715 $\left.\mathrm{cm}^{-1}\right)$ and trans (782 $\mathrm{cm}^{-1}$ ) conformer of $\mathrm{Ch}^{+} . *$ Gauche $\mathrm{Ch}^{+}$location: supercage of FAU zeolite or amorphous solid; Trans $\mathrm{Ch}^{+}$location: sod cage of FAU zeolite; CE location: supercage of FAU zeolite.

(Figure 2A,B). After that, FAU phase begun to arise together with trans $\mathrm{Ch}^{+}$in sod cage band (ca. $782 \mathrm{~cm}^{-1}$ ), while little signal associated with $\mathrm{CE}$ was detected in the solids till $96 \mathrm{~h}$, implying that $\mathrm{Ch}^{+}$rather than $\mathrm{CE}$ plays the key role in the nucleation of high-silica FAU (Figure 2A,B). To gain deeper insight into the nucleation stage, enlarged Raman spectra were also provided with comparison to a calcined zeolite (Figure S21). In addition to the above-mentioned characteristic bands, two extra bands associated with the breathing mode vibrations of S4R (at around $470 \mathrm{~cm}^{-1}$ and $510 \mathrm{~cm}^{-1}$ ), and one band related to bending mode vibrations of D6R in FAU zeolite (at around $290 \mathrm{~cm}^{-1}$ ) have been followed by Raman spectroscopy (Figure 2B, Figure S21).$^{[36]}$ Between 72 and $96 \mathrm{~h}$, a signal associated with $v_{\mathrm{s}}(\mathrm{C}-\mathrm{N})\left(\mathrm{ca} .754 \mathrm{~cm}^{-1}\right)$ of trans $\mathrm{Ch}^{+}$conformer in supercage of $\mathrm{FAU}^{[29]}$ or amorphous solid (latter is more likely, given the amorphous " $\mathrm{Ch}^{+}$only" experiments in Figure S20) was found to occur and then gradually disappeared. In the meantime, a signal attributed to trans $\mathrm{Ch}^{+}$in sod cages (ca. $782 \mathrm{~cm}^{-1}$ ) was witnessed to magnify together with the S4R signal (Figure S21). This means the initial S4R signal should belong to the sod cage, and its construction proceeds concurrently with the transition of external gauche $\mathrm{Ch}^{+}$into trans $\mathrm{Ch}^{+}$in the sod cage. The sod cage construction seems to precede the D6R. Therefore, the nucleation of high-silica FAU zeolite seems to be initiated with the formation of sod cage with trans $\mathrm{Ch}^{+}$conformer occluded rather than the smaller D6R units (only emerging later in Figure 2B), which is believed to be the case for Alrich FAU zeolites. ${ }^{[37,38]}$

The $\mathrm{Ch}^{+}$and $\mathrm{CE}$ amounts also contributed substantially to the zeolite synthesis. According to Figure $2 \mathrm{C}$, the $\mathrm{Ch}^{+}$ amounts in solid products (washed 4 times, each with $50 \mathrm{~mL}$ deionized water) initially kept constant (before $85 \mathrm{~h}$ ) and decreased quickly when crystallinity got enhanced after $96 \mathrm{~h}$. Given that the solid yield decreased with synthesis time, it can be concluded that the excessive $\mathrm{Ch}^{+}$amount was actually present during the nucleation stage. On the contrary, low CE amount was detected during the nucleation period, that is, before $85 \mathrm{~h}$, suggesting that $\mathrm{CE}$ molecules were mainly incorporated into the zeolite during growth (Figure 2C). Interestingly, after the slow nucleation stage, the concurrent increase of trans $\mathrm{Ch}^{+}$amount (from 0.13 to $0.47 \mathrm{mmolg}^{-1}$ solid) was observed with the rapid increase of the $\mathrm{CE}$ amount (from 0.04 to $0.50 \mathrm{mmol} \mathrm{g}^{-1}$ solid) from 85 to $96 \mathrm{~h}$ synthesis time. This indeed proves the symbiosis of both OSDAs, and especially the aid of $\mathrm{CE}$ in the transformation of $\mathrm{Ch}^{+}$from gauche (in amorphous phase or supercage) into trans conformer occluded in sod cages (Figure 2C). As the crystallization finished (after $120 \mathrm{~h}$ ), similar CE amounts were detected in the final product as in FAU-CE. This observation highlights the advantage of the cooperative strategy in OSDA accommodation (Table S6). Because CE can only be settled in the supercage of FAU zeolite, there is evidence to say that the supercage containing $\mathrm{CE}$ was constructed by the assembly of sod cages which were pre-organized during the nucleation step. In summary, the nucleation was initialized with the construction of sod cages containing trans $\mathrm{Ch}^{+}$, while the concomitant occupancy of $\mathrm{CE}$ in the supercages accelerated the assembly of these sod cages, and thus the zeolite crystallization. This also explains why it is difficult to realize the cooperative blueprint for EMT using 18-crown-6 and $\mathrm{Ch}^{+}$, where the more complicated structure (two different supercages and sod cage) requires more delicate assembly of the dual templates within the corresponding units (trials in Figure S22).

To further confirm the key factors in the cooperation strategy, another seven trials were conducted using conditions exactly the same as FAU-CE or FAU-CH except for the additional $\mathrm{Ch}^{+}, \mathrm{CE}$ or seeds (Section 3 in SI). Even though pure FAU zeolites were successfully obtained in all trials, the $\mathrm{CE}$ and $\mathrm{Ch}^{+}$contents therein are obviously lower than those in FAU-CE (CH, S4) (Figure S24-S26, Table S7). Besides, as evidenced in the Raman spectra (samples from Recipe A, C and G), most of the $\mathrm{Ch}^{+}$are occluded as gauche $\mathrm{Ch}^{+}$in the supercage of FAU $\left(715 \mathrm{~cm}^{-1}\right.$ in Raman spectra) instead of trans $\mathrm{Ch}^{+}$in the sod cage $\left(782 \mathrm{~cm}^{-1}\right.$ nearly absent, Fig- 
ure S27). When comparing recipes, the FAU-S4 recipe is far more abundant in organics $\left(\mathrm{Ch}^{+}, \mathrm{CE}\right)$ but deficient in $\mathrm{Na}^{+}$, which indicates that a low $\mathrm{Na}^{+}$amount may be the prerequisite for high-silica FAU synthesis. The cooperative blueprint requires a high organic/ $\mathrm{Na}^{+}$ratio and organic/Al window (Figure S28, Table S7). The latter could also be at the heart of why a distinct assembling route was observed for the highsilica FAU (initiated with sod cage formation).

When excessive $\mathrm{Ch}^{+}$amount is involved in the reactant mixture, the hydrogen bonding between $\mathrm{Ch}^{+}$and surface hydroxyl groups of FAU nuclei could severely restrict the crystal growth rate, as reported recently for KFI zeolite. ${ }^{[39]}$ This explains the relatively smaller crystal sizes found in the high-silica FAU zeolites, that is, $0.1-0.7 \mu \mathrm{m}$ versus those of FAU-CH and FAU-CE $(1.0-1.7 \mu \mathrm{m})$ and commercial FAU zeolite $(0.5-1.0 \mu \mathrm{m})$. (Figure 3, Figure S23, Table 1). Formation of such sub-micrometer sized FAU crystals may prominently benefit their catalytic activity, especially when large substrates are involved in the catalytic reaction.

The catalytic activity of the synthesized high-silica zeolites was therefore tested in LDPE cracking and compared to the performances of existing commercial zeolites. The increasing concern about the inappropriate disposition of plastic in recent years has necessitated a more radical and convenient way for plastic degradation. ${ }^{[40,41]}$ Among the most prevalent strategies, catalyzed pyrolysis is preferred over other methods for its merits of high hydrocarbon yield, source versatility, easy handling (no pre-sorting or washing), and low operation expenses, notably in presence of an eligible solid-state catalyst owning strong Brønsted acid sites. ${ }^{[42-44]}$ In this circumstance, the protonic high-silica FAU zeolites synthesized in this work were applied as catalysts for LDPE degradation with comparison to commercial FAU and USY zeolites. The catalyzed pyrolysis performance was evaluated by the weight loss curves of LDPE pyrolysis (under $\mathrm{N}_{2}$ ) at linearly increas- ing temperature (thus presenting decomposition rates) and the corresponding derivative weight changes (Figure 4A,B). Similar to previous reports, three main regions were distinguished in the pyrolysis process: region 1 corresponds to LDPE mass pyrolysis predominantly occurring on the external and mesoporous surface; region 2 is closely associated with the diffusion of degraded polymeric species into the micropores of zeolites for further degradation and consequently correlates in part with the accessibility of internal acid sites; region 3 matches well with the thermal cracking of LDPE itself (Figure 4B). ${ }^{[4]}$ According to the results, all the protonic high-silica FAU zeolites showed faster degradation than FAU-CH and FAU-CE, corresponding to offset temperatures as low as $285^{\circ} \mathrm{C}$, likely due to their smaller crystal sizes (higher external surface) and higher mesoporous volumes (faster diffusion) (Figures 3, 4, Figure S29, Table 2). Enhanced catalytic activity of nano-sized FAU zeolites, for cracking of other bulky organics, was reported by Mintova, et al. ${ }^{[45]}$ Notably, little activity was observed in region 1 and 2 for FAU-CE, which suggests coke formed on the zeolite surface blocked access to acid sites within its micropores (Figure 4B). Meanwhile, all the high-silica FAU zeolites displayed faster pyrolysis kinetics in region 1 than the existing commercial zeolites, which implies faster degradation rates due to their external or mesoporous surface or their relatively smaller crystal size (Figure 4B, Figure S30).

The LDPE pyrolysis performances were also evaluated by comparing Temp $50 \%$, that is, the temperature at which $50 \%$ of the LDPE mass was lost in pyrolysis. Although H-CBV712 and $\mathrm{H}-\mathrm{CBV} 720$ showed the lowest Temp $50 \%$ values (both $320^{\circ} \mathrm{C}$ ) among the commercial zeolites displayed in Figure S31, their performances were generally inferior to those of protonic high-silica FAU zeolites synthesized in this work $\left(285-295^{\circ} \mathrm{C}\right.$ ) (Figure $\left.4 \mathrm{C}\right)$. Specifically, with a similar bulk Si/ $\mathrm{Al}$ ratio of 6 , H-FAU-S4 (Temp $50 \%$ : $295^{\circ} \mathrm{C}$ ) exhibited
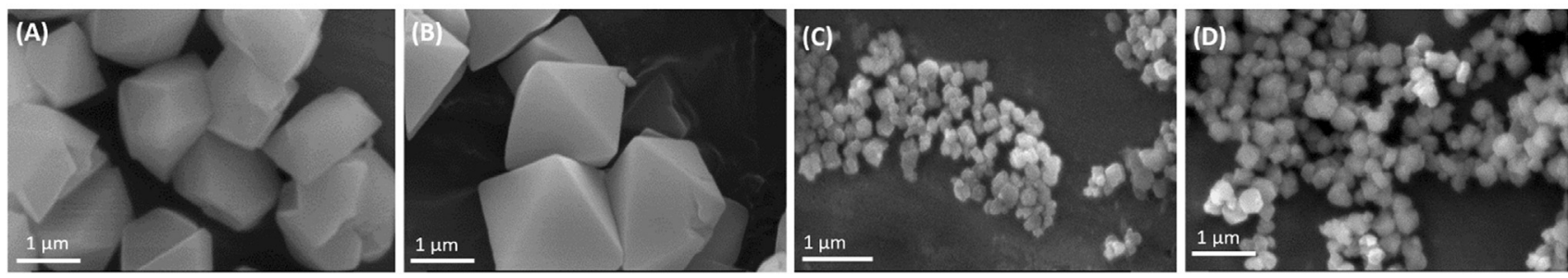

Figure 3. SEM images of as-made A) FAU-CH (Entry 1), B) FAU-CE (Entry 2), C) FAU-S2 (Entry 17), and D) FAU-S3 (Entry 26). For FAU-S1 (Entry 13), FAU-S4 (Entry 39), and commercial FAU zeolites, see Figure S23.

Table 2: The textural properties and acid sites within $\mathrm{H}$-form FAU zeolites synthesized using different methods. ${ }^{[a]}$

\begin{tabular}{|c|c|c|c|c|c|c|c|c|c|c|}
\hline Zeolites & $\mathrm{Si} / \mathrm{Al}$ & $\begin{array}{l}\mathrm{S}_{\text {BET }}\left(\mathrm{S}_{\mathrm{mic}}\right) \\
{\left[\mathrm{m}^{2} \mathrm{~g}^{-1}\right]}\end{array}$ & $\begin{array}{l}V_{\mathrm{t}}\left(V_{\text {mic }}\right) \\
{\left[\mathrm{cm}^{3} \mathrm{~g}^{-1}\right]}\end{array}$ & $\begin{array}{l}V_{\text {meso }} \\
{\left[\mathrm{cm}^{3} \mathrm{~g}^{-1}\right]}\end{array}$ & $\begin{array}{l}\text { BAS } \\
{\left[\mu \mathrm{molg}{ }^{-1}\right]}\end{array}$ & $\begin{array}{l}\text { LAS } \\
{\left[\mu \mathrm{molg}{ }^{-1}\right]}\end{array}$ & $\begin{array}{l}\text { Total Acid Sites } \\
{\left[\mu \mathrm{molg}{ }^{-1}\right]}\end{array}$ & $\begin{array}{l}\text { Total Al } \\
{\left[\mu \mathrm{molg}{ }^{-1}\right]}\end{array}$ & Acid sites/Total Al & $\begin{array}{l}\text { Entry } \\
\text { Number }\end{array}$ \\
\hline $\mathrm{H}-\mathrm{FAU}-\mathrm{CH}$ & 3.5 & $926(823)$ & $0.36(0.31)$ & 0.05 & 847 & 169 & 1016 & 3704 & 0.27 & Entry 1 \\
\hline H-FAU-CE & 4.5 & $725(658)$ & $0.27(0.25)$ & 0.02 & 850 & 172 & 1023 & 3030 & 0.34 & Entry 2 \\
\hline H-FAU-S1 & 4.8 & $926(721)$ & $0.44(0.28)$ & 0.16 & 833 & 147 & 979 & 2874 & 0.34 & Entry 13 \\
\hline H-FAU-S2 & 5.0 & $946(756)$ & $0.44(0.29)$ & 0.15 & 796 & 236 & 1032 & 2778 & 0.37 & Entry 17 \\
\hline H-FAU-S3 & 5.8 & 946 (799) & $0.40(0.30)$ & 0.10 & 763 & 173 & 936 & 2451 & 0.38 & Entry 26 \\
\hline H-FAU-S4 & 6.0 & 926 (789) & $0.41(0.30)$ & 0.11 & 765 & 145 & 910 & 2381 & 0.38 & Entry 39 \\
\hline H-CBV712 & 6.0 & $806(616)$ & $0.44(0.24)$ & 0.20 & 421 & 103 & 524 & 2381 & 0.22 & - \\
\hline
\end{tabular}

[a] See more calculation details for the textual properties and acid site amounts in section S2 of the Supporting Information. 

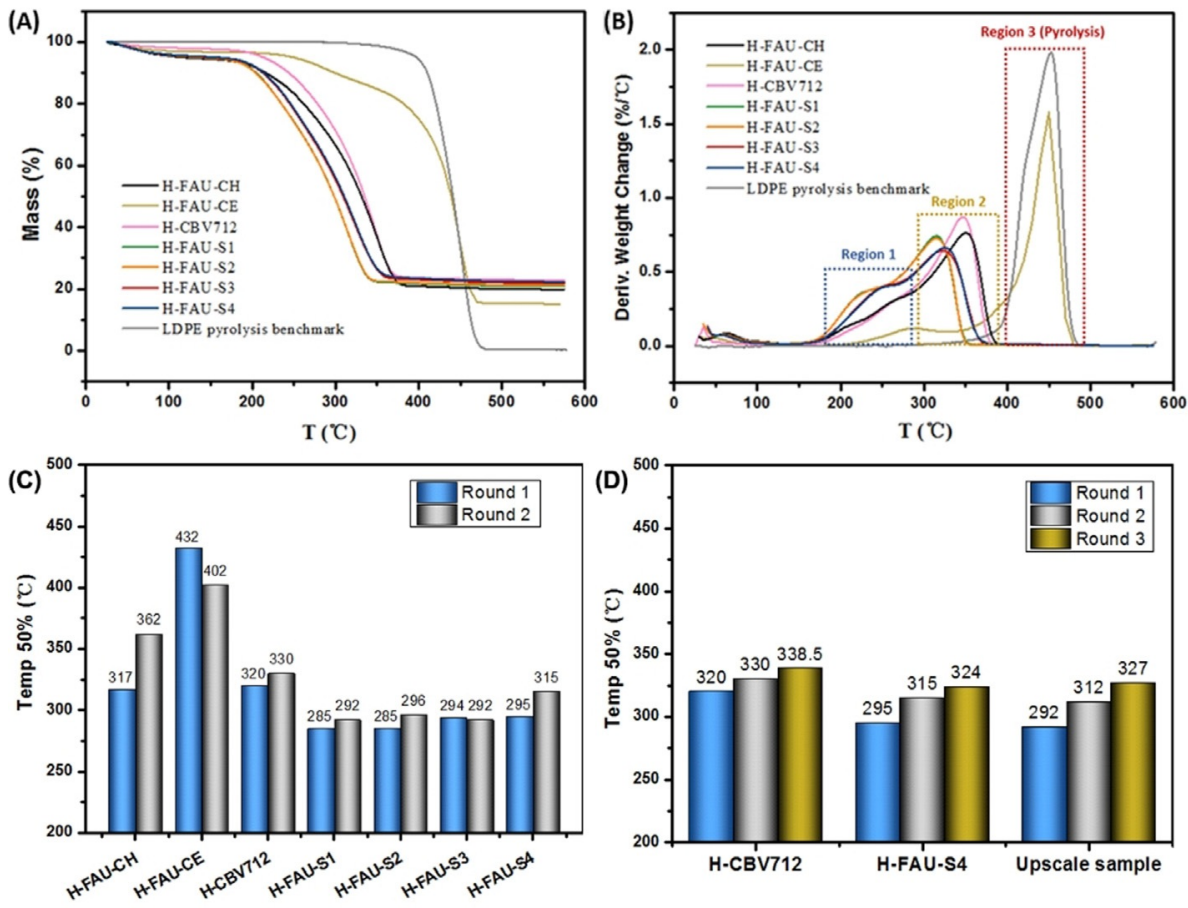

Figure 4. A) Weight loss curves of LDPE pyrolysis and B) the corresponding derivative weight changes during LDPE pyrolysis using highly siliceous H-form FAU zeolites as catalysts. The curves of FAU-S1 (Entry 13, green) and FAU-S2 (Entry 17, orange) overlap in (A) and (B), similar for the curves of FAU-S3 (Entry 26, red) and FAU-S4 (Entry 39, blue). All the tests were duplicated and showed little deviations. C) Temperature for $50 \%$ conversion (Temp 50\%) of LDPE pyrolysis in two consecutive pyrolysis-regeneration cycles using $\mathrm{H}$-form FAU zeolites synthesized in this work and a commercial H-CBV712 benchmark zeolite as catalysts. LDPE pyrolysis without catalyst has a Temp $50 \%$ of $441^{\circ} \mathrm{C}$. See more LDPE pyrolysis results in Figure S30,S31. D) Temp 50\% in three consecutive pyrolysis-regeneration cycles using H-CBV712, H-FAU-S4 (Entry 39) and the upscale sample of H-FAU-S4 (Entry 57) as catalysts.

considerably higher LDPE decomposition activity than $\mathrm{H}$ CBV712 (Temp $50 \%: 320^{\circ} \mathrm{C}$ ) even though the latter one has a larger mesoporous volume (top-down dealumination; Figure $4 \mathrm{C}$, Table 2). This highlights the distinct and unique framework acidity of the bottom-up high-silica FAU zeolite. Pyridine-IR was conducted to assess the acidity of zeolites. As shown in Table 2, significantly higher amounts of Lewis acid sites (LAS) and Brønsted acid sites (BAS) were obtained in H-FAU-S4 than in commercial H-CBV712, which shows a higher accessibility of the strong acid sites in H-FAU-S4. This is also evident from the higher "Acid sites/Total Al" ratio. Over this zeolite, the amount of BAS $\left(0.76 \mathrm{mmol} \mathrm{g}^{-1}\right)$ was very comparable to the amount of $\mathrm{CE}\left(0.75 \mathrm{mmol} \mathrm{g}^{-1}\right)$ (Table 2 and Figure 2C), which may (very tentatively) indicate a controlled Al-siting which translated to the presence of one strong acid site in each supercage of this zeolite. Besides, LAS and BAS amounts together with the "Acid sites/Total Al" ratios were kept at approximate levels for all the high-silica FAU zeolites even though the absolute $\mathrm{Al}$ amounts decreased (from S1 to S4). The non-detected $\mathrm{Al}$ in pyridine-IR measurements should mainly correspond to those $\mathrm{Al}$ contents in sod cage or to weak acid Al species. ${ }^{[4-48]}$ These results explicitly confirm that unique $\mathrm{Al}$ distributions have been obtained in the high-silica FAU zeolites prepared via the presented cooperative OSDA strategy, which has never been reported before in literature regarding high-silica FAU zeolites.
Since deactivation of catalysts due to coke formation is a common issue in pyrolysis, regeneration tests were performed to investigate the recyclability of the high-silica zeolites. Except for H-FAU-CH and H-CBV300, minor changes of Temp $50 \%$ values have been observed in all catalysts after regeneration (under oxygen flow), indicating that the zeolite activity was mostly recovered by simple oxygen treatment (Figure 4C, Figure S31). Therein, the Temp $50 \%$ value of $\mathrm{H}-\mathrm{FAU}-\mathrm{S} 4$ increased to $315^{\circ} \mathrm{C}$ after regeneration, which remained lower than that of $\mathrm{H}-\mathrm{CBV} 712\left(330^{\circ} \mathrm{C}\right)$, even though the change of Temp 50\% in the former sample is more significant (Figure 4C). The slightly larger coke amount in H-FAU-S4, as shown in Figure S32, could be explained by its higher acid site density (Table 2). To further clarify the thermal stability of the catalysts, we have conducted a third pyrolysis-regeneration cycle on H-FAU-S4 and a sample made in a scale-up FAU-S4 synthesis ("upscale") with comparison to $\mathrm{H}-\mathrm{CBV} 712$, which has the same $\mathrm{Al}$ content. As shown, almost identical Temp $50 \%$ changes $\left(\approx 9^{\circ} \mathrm{C}\right)$ were found on H-FAU-S4 and H-CBV712 between the second and third cycle (Figure 4D). As a result, the absolute Temp 50\% values on H-FAU-S4 and its upscale sample (which demonstrates reproducibility in synthesis and catalysis) are still lower than that on $\mathrm{H}-\mathrm{CBV} 712$, which proves the better performance of high-silica FAU zeolite in the long term, and seemingly corroborates their good thermal stability (Figure 4D). Finally, the XRD patterns were collected after two consecutive pyrolysis-regeneration cycles (Figure S33). Little 
structural deterioration was found on all the high-silica FAU zeolites, which confirms their excellent rigidity. Therefore, the high-silica FAU zeolites synthesized in this work are preferred LDPE pyrolysis catalysts surpassing both the FAU zeolites prepared by single OSDA and the commercial USY zeolites, not only for their excellent structural and chemical stability, but also for their faster LDPE degradation rates.

\section{Conclusion}

High-silica FAU zeolites could be synthesized taking advantage of the synergy between $\mathrm{Ch}^{+}$and $\mathrm{CE}$ as dual structure-directing agents. The synthesis parameters have been carefully investigated to capture the trans $\mathrm{Ch}^{+}$within the sod cages of FAU zeolites. The addition of $\mathrm{CE}$ as a cooperative OSDA could greatly promote the fraction of trans $\mathrm{Ch}^{+}$in sod cage at a fixed $\mathrm{Ch}^{+}$amount in each unit cell. As a result, less $\mathrm{Na}^{+}$, and therefore less $\mathrm{Al}$ content, is necessitated in sod (and other) cages because of the more severe steric hindrance and repulsive electrostatic forces within the sod cage, as well as the full occupancy of supercage by $\mathrm{CE}$ and gauche $\mathrm{Ch}^{+}$. The unique OSDA strategy leads to different $\mathrm{Al}$ siting and acid site distributions within the FAU zeolites and high $\mathrm{Si} / \mathrm{Al}$ ratios in a reproducible way, with few seeds needed. In contrast, no trans $\mathrm{Ch}^{+}$conformer in sod cages was encountered when $\mathrm{Ch}^{+}$ was adopted as the only OSDA. The mechanistic study disclosed that the construction of sod cages containing trans $\mathrm{Ch}^{+}$was the likely key step in nucleation, followed by the formation of supercage from sod cage assembly with the assistance of CE. Finally, excellent LDPE pyrolysis performances were observed on the protonic high-silica FAU zeolites due to their smaller crystal sizes and unique acid site distributions. We believe that we have proven a true (with direct evidence) and facile cooperation strategy for OSDAs, which includes a flexible (conformer-prone) and a bulky one, and that this strategy could effectively steer their accommodation in certain growing confined environments. It may be a promising way to modify not only $\mathrm{Al}$ contents, but also the Al distribution and siting of catalytically relevant zeolites. The novel and stable high-silica FAUs with $\mathrm{Si} / \mathrm{Al}$ ratios over 6 (attained without dealumination protocols) offer access to uniquely acidic and stable $\mathrm{Y}$ zeolites, and a range of relevant catalytic applications could now be explored.

\section{Acknowledgements}

This work was performed in the framework of a KU Leuven C1-and FWO projects. Q.K. and M.D. acknowledge "Internal Funds KU Leuven C12/18/005" for funding. Q.K. acknowledges the assistance from Wei Zhang for the SEM image and from Xiaohua Li for the Raman tests. I.K. acknowledges "FWO Vlaanderen" (grant $1260321 \mathrm{~N}$ ) for financial support. Z.L. acknowledges the Senior FWO Postdoctoral Fellowship (grant 12ZI920N). B.S. thanks WATCH for funding, a VLAIO Catalisti SBO project. M.D. acknowledges KU Leuven BOFZAP for his appointment. D.S. and R.O.-S. acknowledge
"FWO Vlaanderen" (grant PorMedNMR nr. G0D5419N) and "Internal Funds KU Leuven STG/18/022".

\section{Conflict of Interest}

The authors declare no conflict of interest.

Keywords: acid site distribution - cooperative OSDA .

FAU zeolite · pyrolysis · siliceous materials

[1] M. Dusselier, M. E. Davis, Chem. Rev. 2018, 118, 5265-5329.

[2] Y. Liao, S. F. Koelewijn, G. van den Bossche, J. van Aelst, S. van den Bosch, T. Renders, K. Navare, T. Nicolaï, K. van Aelst, M. Maesen, et al., Science 2020, 367, 1385-1390.

[3] M. E. Davis, R. F. Lobo, Chem. Mater. 1992, 4, $756-768$.

[4] P. Sudarsanam, E. Peeters, E. V. Makshina, V. I. Parvulescu, B. F. Sels, Chem. Soc. Rev. 2019, 48, 2366-2421.

[5] I. Khalil, H. Jabraoui, S. Lebègue, W. J. Kim, L. J. Aguilera, K. Thomas, F. Maugé, M. Badawi, Chem. Eng. J. 2020, 402, 126264.

[6] I. Khalil, G. Quintens, T. Junkers, M. Dusselier, Green Chem. 2020, 22, 1517-1541.

[7] I. Khalil, C. M. Celis-Cornejo, K. Thomas, P. Bazin, A. Travert, D. J. Pérez-Martínez, V. G. Baldovino-Medrano, J. F. Paul, F. Maugé, ChemCatChem 2020, 12, 1095-1108.

[8] J. W. Park, J. H. Kim, G. Seo, Polym. Degrad. Stab. 2002, 76, $495-501$.

[9] B. Xu, S. Bordiga, R. Prins, J. A. van Bokhoven, Appl. Catal. A 2007, 333, 245-253.

[10] R. A. Beyerlein, B. Mcvicker, L. N. Yacullo, J. J. Ziemiak, J. Phys. Chem. 1988, 92, 1967-1970.

[11] M. A. Camblor, A. Corma, A. Martínez, F. Mocholí, J. PérezPariente, Appl. Catal. 1989, 55, 65-74.

[12] Z. Qin, K. A. Cychosz, G. Melinte, H. El Siblani, J. P. Gilson, M. Thommes, C. Fernandez, S. Mintova, O. Ersen, V. Valtchev, J. Am. Chem. Soc. 2017, 139, 17273-17276.

[13] G. Agostini, C. Lamberti, L. Palin, M. Milanesio, N. Danilina, B. Xu, M. Janousch, J. A. Van Bokhoven, V. Uni, A. A. V. Orientale, et al., J. Am. Chem. Soc. 2010, 132, 667-678.

[14] D. Verboekend, G. Vilé, J. Pérez-ramírez, Adv. Funct. Mater. 2012, 22, 916-928.

[15] Z. Qin, W. Shen, S. Zhou, Y. Shen, C. Li, P. Zeng, B. Shen, Microporous Mesoporous Mater. 2020, 303, 110248.

[16] T. Ennaert, J. Van Aelst, J. Dijkmans, R. De Clercq, W. Schutyser, M. Dusselier, D. Verboekend, B. F. Sels, Chem. Soc. Rev. 2016, 45, 584-611.

[17] D. Kerstens, B. Smeyers, J. Van Waeyenberg, Q. Zhang, J. Yu, B. F. Sels, Adv. Mater. 2020, 32, 2004690.

[18] M. D. Oleksiak, K. Muraoka, M. F. Hsieh, M. T. Conato, A. Shimojima, T. Okubo, W. Chaikittisilp, J. D. Rimer, Angew. Chem. Int. Ed. 2017, 56, 13366-13371; Angew. Chem. 2017, 129 , $13551-13556$.

[19] J. Wang, P. Liu, M. Boronat, P. Ferri, Z. Xu, P. Liu, B. Shen, Z. Wang, J. Yu, Angew. Chem. Int. Ed. 2020, 59, 17225-17228; Angew. Chem. 2020, 132, 17378-17381.

[20] H. Kacirek, H. Lechert, J. Phys. Chem. 1976, 80, 1291-1296.

[21] D. Zhu, L. Wang, D. Fan, N. Yan, S. Huang, S. Xu, P. Guo, M. Yang, J. Zhang, P. Tian, et al., Adv. Mater. 2020, 32, 2000272.

[22] M. Moliner, C. Martínez, A. Corma, Chem. Mater. 2014, 26, $246-$ 258.

[23] J. E. Schmidt, D. Fu, M. W. Deem, B. M. Weckhuysen, Angew. Chem. Int. Ed. 2016, 55, 16044-16048; Angew. Chem. 2016, 128, $16278-16282$. 
[24] M. Dusselier, J. H. Kang, D. Xie, M. E. Davis, Angew. Chem. Int. Ed. 2017, 56, 13475-13478; Angew. Chem. 2017, 129, 1366013663.

[25] M. A. Miller, J. G. Moscoso, S. C. Koster, M. G. Gatter, G. J. Lewis, Stud. Surf. Sci. Catal. 2007, 170, 347-354.

[26] Y. Lee, M. B. Park, P. S. Kim, A. Vicente, C. Fernandez, I. S. Nam, S. B. Hong, ACS Catal. 2013, 3, 617-621.

[27] J. Bae, J. Cho, J. H. Lee, S. M. Seo, S. B. Hong, Angew. Chem. Int. Ed. 2016, 55, 7369-7373; Angew. Chem. 2016, 128, 7495-7499.

[28] T. Inoue, M. Itakura, H. Jon, Y. Oumi, A. Takahashi, T. Fujitani, T. Sano, Microporous Mesoporous Mater. 2009, 122, 149-154.

[29] J. Bae, S. B. Hong, Chem. Sci. 2018, 9, 7787-7796.

[30] F. Delprato, L. Delmotte, J. L. Guth, L. Huve, Zeolites 1990, 10, 546-552.

[31] S. L. Burkett, M. E. Davis, Microporous Mater. 1993, 1, 265-282.

[32] E. J. P. Feijen, K. De Vadder, M. H. Bosschaerts, J. L. Lievens, J. A. Martens, P. J. Grobet, P. A. Jacobs, J. Am. Chem. Soc. 1994, 116, 2950-2957.

[33] D. He, D. Yuan, Z. Song, Y. Xu, Z. Liu, Chin. J. Catal. 2019, 40, $52-59$.

[34] J. Klinowski, J. M. Thomas, C. A. Fyfe, G. C. Gobbi, Nature 1982, 296, 533-536.

[35] X. S. Zhao, G. Q. Lu, A. K. Whittaker, G. J. Millar, H. Y. Zhu, J. Phys. Chem. B 1997, 101, 6525-6531.

[36] J. Zhang, Y. Chu, F. Deng, Z. Feng, X. Meng, F. Xiao, Inorg. Chem. Front. 2020, 7, 2204-2211.

[37] M. Ogura, Y. Kawazu, H. Takahashi, T. Okubo, Chem. Mater. 2003, 15, $2661-2667$.
[38] M. Iwama, Y. Suzuki, J. Pl, K. Itabashi, M. Ogura, T. Okubo, Cryst. Growth Des. 2010, 10, 3471-3479.

[39] J. Yang, X. Tang, J. Liu, J. Wang, H. Shang, L. Wu, J. Li, S. Deng, Chem. Eng. J. 2021, 406, 126599.

[40] J. R. Jambeck, R. Geyer, C. Wilcox, T. R. Siegler, M. Perryman, A. Andrady, R. Narayan, K. L. Law, Science 2015, 347, 768-771.

[41] A. Chamas, H. Moon, J. Zheng, Y. Qiu, T. Tabassum, J. H. Jang, M. Abu-Omar, S. L. Scott, S. Suh, ACS Sustainable Chem. Eng. 2020, 8, 3494-3511.

[42] C. Dorado, C. A. Mullen, A. A. Boateng, ACS Sustainable Chem. Eng. 2014, 2, 301-311.

[43] K. Ragaert, L. Delva, K. Van Geem, Waste Manage. 2017, 69, $24-58$.

[44] A. Maity, S. Chaudhari, J. J. Titman, V. Polshettiwar, Nat. Commun. 2020, 11, 3828 .

[45] H. Awala, J. P. Gilson, R. Retoux, P. Boullay, J. M. Goupil, V. Valtchev, S. Mintova, Nat. Mater. 2015, 14, 447-451.

[46] S. Bordiga, C. Lamberti, F. Bonino, A. Travertd, F. ThibaultStarzykd, Chem. Soc. Rev. 2015, 44, $7262-7341$.

[47] I. Khalil, K. Thomas, H. Jabraoui, P. Bazin, F. Maugé, J. Hazard. Mater. 2020, 384, 121397.

[48] F. Brandi, I. Khalil, M. Antonietti, M. Al-Naji, ACS Sustainable Chem. Eng. 2021, 9, 927-935. 